\title{
Experimental study on the effect of vitamin C administration on lipid peroxidation and antioxidant enzyme activity in rats exposed to chlorpyriphos and lead acetate
}

\author{
Nisar Ahmad Nisar ${ }^{1}$, Mudasir Sultana², Hina Ashraf Waiz³ ${ }^{3}$ Parveez Ahmad Para ${ }^{4}$, Naseer Ahmad Baba ${ }^{5}$, \\ Fayaz Ahmad Zargar ${ }^{6}$ and Waseem Hussain Raja ${ }^{7}$
}

\begin{abstract}
1. Division of Veterinary Pharmacology and Toxicology, Arawali Vaterinary College Sikar-332001, Rajasthan, India Email: nisar583@gmail.com; 2. Division of veterinary pharmacology and toxicology SKUAST- J, RS Pura 181102, India, Email:Mudasir786@gmail.com; 3. Division of Livestock Production and Management SKUAST -K, Shuhama Srinagar, 190001, India, Email:dr_hinawaiz@yahoo.com; 4. Division of Livestock Products Technology SKUAST- J, RS Pura 181102, India, Parveezpara621@gmail.com; 5. Division of Veterinary pharmacology and toxicology SKUAST- J, RS Pura 181102, India, Email:baba96@gmail.com; 6. Division of Livestock Products Technology SKUAST- J, RS Pura 181102, India, Koolfz71@gmail.com; 7. Division of Livestock Products Technology SKUAST- J,

RS Pura 181102, India, Email:Mailwaseem123@gmail.com
\end{abstract}

Corresponding author: Nisar Ahmad Nisar, Email: nisar583@gmail.com

Received: 11-01-2013, Accepted: 09-02-2013, Published online: 04-05-2013

How to cite this article: Nisar NA, Sultana M, Waiz HA, Para PA, Baba NA, Zargar FA and Raja WH (2013) Experimental study on the effect of vitamin $C$ administration on lipid peroxidation and antioxidant enzyme activity in rats exposed to chlorpyriphos and lead acetate, Vet World 6(8):461-466, doi:10.5455/vetworld.2013.461-466

\begin{abstract}
Aim : To evaluate the effects of chlorpyriphos, lead acetate, vitamin $\mathrm{C}$ alone, and in combination on the activity of oxidative stress parameters in wistar rats.

Marerial and Methods: Rats of 150-200g body weight were divided into eight groups of six animals each and were subjected to various daily oral treatment regimes for 98 days. Group I served as control receiving only corn oil, group II received chlorpyriphos@ $9.5 \mathrm{mg} / \mathrm{kg}$ in corn oil, group III received lead acetate @100 ppm in water, whereas animals in group IV ${ }^{\text {th }}$ received a combination of chlorpyriphos@ $9.5 \mathrm{mg} / \mathrm{kg}$ in corn oil and lead acetate @ 100 ppm in water. Group V $\mathrm{V}^{\mathrm{th}}$ received vitamin C @ 100mg/kg in water, group VI ${ }^{\text {th }}$ received a combination of chlorpyriphos@ @.5mg/kg and vitamin C @ $100 \mathrm{mg} / \mathrm{kg}$, group VII ${ }^{\text {th }}$ received lead acetate @ 100 ppm in water and vitamin C @ 100mg $/ \mathrm{kg}$ and group VIII ${ }^{\text {th }}$ received chlorpyriphos@5.5mg/kg, lead acetate@100ppm in water and vitamin C@100mg $/ \mathrm{kg}$.

Results: Administration of both chlorpyriphos and lead acetate caused a significant decrease in oxidative stress parameters viz. blood glutathione, catalase, superoxide dismutase (SOD), glutathione peroxidase (GPx), glutathione-s-transferase (GST) along with a significant increase in lipid peroxidation level when given alone or in combination.

Conclusions: The study demonstrated that treatment of chlorpyriphos and lead treated rats with vitamin $\mathrm{C}$ significantly improved some of altered oxidative stress parameters revealing the protective effect of this vitamin $\mathrm{C}$ against oxidative stress induced by chlorpyriphos and lead.
\end{abstract}

Keywords: chlorpyriphos, lead acetate, oxidative stress, vitamin C

\section{Introduction}

Organophosphates (OP) were first synthesized in Germany before the Second World War and now there have been an estimated 300,000 severe pesticide poisoning events reported worldwide, mostly due to them. Organophosphates, among other pesticides are the most toxic to the vertebrates [1,2]. Poisoning occurs as a result of agricultural use, suicide or accidental exposure [3]. Apart from inhibition of cholinesterase and presence of cholinergic effects, oxidative stress has been reported by many authors as one of the adverse effects in poisoning by OP in both humans and animals. On the basis of relevant literature it is concluded, that determination of oxidative stress parameters can be useful for monitoring people exposed to OP professionally.

This article is an open access article licensed under the terms of the Creative Commons Attribution License (http://creativecommons. org/licenses/by/2.0) which permits unrestricted use, distribution and reproduction in any medium, provided the work is properly cited.
Chlorpyriphos, a phosphorothioate organophosphorus insecticide is metabolically activated through oxidative desulfuration to chlorpy-riphos oxon by cytochrome $\mathrm{P}_{450}$. Chlorpyriphos oxon binds to acetylcholinesterase, inhibiting its ability to hydrolyze the neurotransmitter acetylcholine. Both chlorpyriphos and its oxon are metabolized to 3, 5, 6-trichloro-2pyridinol by mixed functions oxidase system and induce oxidative stress which may constitute significantly to overall toxicity [4]. Chlorpyriphos produced oxidative stress results in the accumulation of lipid peroxidation products in different organs of rats [5] and has also been shown to damage DNA [1].

It is now well recognized that humans and animals are exposed to more than one chemical concurrently from various sources such as food, air, water and consumer products (including some heavy metals and pesticides). Organophosphorus insecticides (OPI's) like other insecticides form chelating complexes with some heavy metals like lead, mercury and copper. Oxidative stress changes are the sequelae of toxicities 
of both organophosphates and some heavy metals. In recent years, lead has become a regulatory concern and subject of much interest among pharmacologists, environmental scientists and clinicians due to its continuous emission from industrial sources and automobile exhausts and its pharmacological behavior to remain bound to mammalian tissues, particularly in bones for a long duration. Organic lead is more evenly distributed between erythrocytes and soft tissue and less likely to accumulate in bone than inorganic lead due to its higher lipid solubility and thus cause oxidative stress.

There are several mechanisms to counteract the damage caused by reactive oxygen species (ROS) in the human and animal organism. One of them is the enzymatic system which consists of such enzymes as superoxide dismutase (SOD) (manganese in the active enzymatic centre or copper and zinc), catalase (CAT), glutathione peroxidase (GPx) and glutathione reductase (GR). Another antioxidative system is nonenzymatic and consists of a reduced form of glutathione (GSH) and vitamins such as vitamin C, vitamin E and beta-carotene. Each of these antioxidative systems has a specific activity/concentration, but they work synergistically generated. Vitamin C and Vitamin E are reported to act as effective antioxidants for protection against diseases and degenerative process caused by oxidative stress [6]. Vitamin $\mathrm{C}$ has been studied extensively in modulating lead intoxication. It acts mainly as an antioxidant molecule and its beneficial effects could be attributed to its ability to complex with lead [7]. Thus, the administration of vitamin $\mathrm{C}$ may augment the function of endogenous free radical scavengers and consequently decrease the deleterious effects of free radicals on body cells.

The present study was thus conducted to access the ameliorative effect of vitamin $\mathrm{C}$ on the oxidative stress changes induced by administration of chlorpyriphos and lead acetate.

\section{Materials and Methods}

Experimental animals: The Wister rats weighing between 150-200 gm used in the present study were procured from Indian institute of integrative medicine (IIIM), Council of scientific and industrial research, (CSIR) Lab, Jammu, India.

Ethical approval: All rats were maintained under standard environmental conditions with ad libitum feed and water. The animals were treated humanely during the whole period of experimental study and the work was considered by the institutional Animal Ethics Committee vide No. AU/FVSc/C-11/2456-68 on ethical standards in animal experimentation.

Chemicals: Chlorpyriphos $(20 \% \mathrm{w} / \mathrm{v})$, used was commercially obtained from Tata Rallis India Limited, Mumbai as Tafaban in 1litre pack. Lead acetate $(99.9 \%$ pure) and ascorbic acid (99.9\% pure) were purchased from Hi-Media Labs Mumbai. All other chemicals used in the study were of extra pure quality and purchased from Hi-media, S.d. Fine Chem. Pvt. Ltd., Qualigens Chem. (Mumbai, India) and E. Merck (Mumbai, India).

Experimental Design: These rats were randomly allocated to eight groups of six rats each and subjected to various daily treatment regimes for 98 days. Group I served as control receiving only corn oil, group II received chlorpyriphos @ $5.5 \mathrm{mg} / \mathrm{kg} .\left(1 / 25^{\text {th }} \mathrm{LD}_{50}\right)$ in corn oil, group III received lead acetate @ 100 ppm in water, whereas animals in group $\mathrm{IV}^{\mathrm{th}}$ received a combination of chlorpyriphos@ @ $5.5 \mathrm{mg} / \mathrm{kg}$ in corn oil and lead acetate@100 ppm in water. Group V ${ }^{\text {th }}$ received vitamin C @ 100mg/kg in water, group VI ${ }^{\text {th }}$ received a combination of chlorpyriphos@5.5mg/kg and vitamin C@100mg $/ \mathrm{kg}$, group VII ${ }^{\text {th }}$ received lead acetate@100 ppm in water and vitamin C@ $100 \mathrm{mg} / \mathrm{kg}$ and group VIII ${ }^{\text {th }}$ received chlorpyriphos@ $5.5 \mathrm{mg} / \mathrm{kg}$, lead acetate @ $100 \mathrm{ppm}$ in water and vitamin C @ $100 \mathrm{mg} / \mathrm{kg}$. The administration of the toxicants was carried out between 9:30-10:30 AM daily upto 98 days.

All the rats were weighed at weekly intervals during exposure with toxicants and necessary corrections in dosages were made according to the changes in the body weight. Blood samples were collected at zero, $30^{\text {th }}, 60^{\text {th }}$ and $98^{\text {th }}$ day of experimental study, for which the animals were anaesthetized with diethyl ether. Blood samples were collected from retroorbital fossa using capillary tubes in aliquots containing heparin@10 IU/ml of blood. The red blood cells were washed with normal saline solution thrice, before preparing the RBC lysate. RBC sediment obtained after harvesting of plasma was diluted with normal saline solution in the ratio of $1: 1$ on $\mathrm{v} / \mathrm{v}$ basis and mixed gently and thoroughly. The diluted erythrocytes were centrifuged for $10 \mathrm{~min}$. After centrifugation the supernatant was discarded along with buffy coat and again NSS was added to the RBC on $\mathrm{v} / \mathrm{v}$ basis, mixed gently and then centrifuged. This process was repeated thrice. After final washing 1 per cent haemolysate $(100 \mu 1$ washed $\mathrm{RBC}+9.9 \mathrm{ml} \mathrm{PBS})$ and 33 per cent hemolysate $(330 \mu 1$ washed $\mathrm{RBC}+$ $670 \mu 1$ PBS) in phosphate buffer solution (PBS), $\mathrm{pH} 7.4$ were prepared. The 1 percent haemolysate was used for the estimation of catalase, superoxide-dismutase, glutathione-peroxidase and glutathione-s-transferase and 33 per cent haemolysate was used for estimation of lipid peroxidation.

Statistical analysis: Standard statistical procedures were followed and the data collected during the experiment was subjected to analysis of variance which was carried in completely randomized design (CRD). The significance was assayed at $5 \%(P<0.05)$ levels.

\section{Results and Discussion}

Association between oxidative stress and adverse health effects have been suggested for several groups 
Table-1. Effect of repeated oral administration of chlorpyriphos, lead acetate, vitamin $\mathrm{C}$ alone, and in combinations on erythrocyte lipid peroxidation ( $\mathrm{n}$ mole MDA formed/ml erythrocytes) in rats.

\begin{tabular}{|c|c|c|c|c|}
\hline Treatment group & Zero day & 30th day & 60th day & 98th day \\
\hline Group I & $4.59 \pm 0.29$ & $5.44 \pm 0.19^{\mathrm{ab}}$ & $5.09 \pm 0.34^{a}$ & $4.05 \pm 0.07^{\mathrm{a}}$ \\
\hline Group II & $5.51 \pm 0.29$ & $7.23 \pm 0.31^{c}$ & $8.25 \pm 0.37^{c}$ & $9.85 \pm 0.19^{d}$ \\
\hline Group III & $5.48 \pm 0.06$ & $6.33 \pm 0.16^{\mathrm{ab}}$ & $8.31 \pm 0.44^{c}$ & $9.49 \pm 0.39^{d}$ \\
\hline Group IV & $5.56 \pm 0.28$ & $6.80 \pm 0.21^{\mathrm{bc}}$ & $8.94 \pm 0.24^{c}$ & $12.32 \pm 0.57^{\mathrm{d}}$ \\
\hline Group V & $5.00 \pm 0.16$ & $5.32 \pm 0.27^{a}$ & $5.11 \pm 0.21^{a}$ & $4.72 \pm 0.14^{a}$ \\
\hline Group VI & $4.23 \pm 0.09$ & $5.61 \pm 0.34^{\mathrm{ab}}$ & $6.41 \pm 0.21^{b}$ & $6.42 \pm 0.23^{\mathrm{b}}$ \\
\hline Group VII & $5.08 \pm 0.15$ & $5.92 \pm 0.37^{\mathrm{abc}}$ & $6.54 \pm 0.24^{b}$ & $6.38 \pm 0.14^{b}$ \\
\hline Group VIII & $5.33 \pm 0.24$ & $6.47 \pm 0.25^{\mathrm{abc}}$ & $6.71 \pm 0.25^{\mathrm{b}}$ & $7.80 \pm 0.33^{\mathrm{c}}$ \\
\hline
\end{tabular}

Values given are mean \pm SE of the results obtained from 6 animals.

Means with at least one common superscript do not differ significantly at $5 \%(P<0.05)$

Table-2. Effect of oral administration of chlorpyriphos, lead acetate, vitamin $\mathrm{C}$ alone, and in combinations on blood glutathione levels $(\mathrm{nmol} / \mathrm{ml})$ in rats.

\begin{tabular}{lllll}
\hline Treatment group & Zero day & 30th day & 60th day & 98th day \\
\hline Group I & $52.65 \pm 1.80$ & $51.03 \pm 1.15$ & $52.65 \pm 2.60^{\mathrm{c}}$ & $51.67 \pm 1.45^{\mathrm{de}}$ \\
Group II & $52.01 \pm 2.20$ & $50.32 \pm 2.02$ & $45.54 \pm 0.88^{\mathrm{ab}}$ & $37.82 \pm 1.02^{\mathrm{ab}}$ \\
Group III & $52.20 \pm 1.52$ & $53.69 \pm 1.60$ & $47.00 \pm 1.00^{\mathrm{abc}}$ & $42.00 \pm 1.15^{\mathrm{bc}}$ \\
Group IV & $50.00 \pm 1.15$ & $51.27 \pm 1.84$ & $42.50 \pm 1.43^{\mathrm{a}}$ & $36.66 \pm 0.88^{\mathrm{a}}$ \\
Group V & $50.65 \pm 2.90$ & $49.54 \pm 2.90$ & $50.85 \pm 3.56^{\mathrm{bc}}$ & $52.80 \pm 2.45^{\mathrm{e}}$ \\
Group VI & $54.56 \pm 1.20$ & $48.67 \pm 1.82$ & $50.43 \pm 2.51^{\mathrm{bc}}$ & $47.33 \pm 1.45^{\mathrm{cd}}$ \\
Group VII & $47.67 \pm 0.88$ & $44.30 \pm 1.20$ & $46.73 \pm 0.72^{\mathrm{abc}}$ & $44.42 \pm 0.33^{\mathrm{c}}$ \\
Group VIII & $48.00 \pm 2.16$ & $46.43 \pm 1.91$ & $45.67 \pm 2.75^{\mathrm{ab}}$ & $44.00 \pm 2.10^{\mathrm{c}}$ \\
\hline
\end{tabular}

Values given are mean \pm SE of the results obtained from 6 animals. Means with at least one common superscript do not differ significantly at $5 \%(P<0.05)$

of diseases such as cardiovascular, respiratory, neurological as well as for the general ageing process. Several drugs, xenobiotics and environmental pollutants are known to cause this imbalance between formation and removal of reactive oxygen species (ROS). Xenobiotics comprise an important source of ROS, which are produced in cells during normal metabolic processes involving oxygen. However presence of ROS may be significantly increased by exposure to different environmental toxicants produced from the industry, agriculture, tobacco smoke or pollution accidents. Biological antioxidants including vitamins can prevent the uncontrolled formation of free radicals and activated oxygen species or inhibit their reaction with biological structures. The destruction of most free radicals and activated oxygen species rely on the oxidation of endogenous antioxidants mainly scavenging and reducing molecules. Reactive oxygen species and malondialdehyde are involved in promotion and progression of carcinogenesis. Their increased production may cause cellular and molecular damage leading to lipid peroxidation as well as mutations in tumor suppressor gene or the genes of antioxidant enzymes. Malondialdehyde (MDA) is the end point of lipid peroxidation process which may be defined as an oxidative deterioration of polyunsaturated lipids. Lipid peroxidation has been measured by quantifying the thiobarbituric acid reactive substances. During the current study it was observed that lipid peroxidation level (Table-1) in group II showed significant increase on $30^{\text {th }}, 60^{\text {th }}$ and $98^{\text {th }}$ day as compared to group I on said dates. Also a significant increase in lipid peroxidation was observed on $60^{\text {th }}$ and $98^{\text {th }}$ day in groups III, IV ${ }^{\text {th }}, \mathrm{VI}^{\text {th }}, \mathrm{VII}^{\text {th }}$ and $\mathrm{VIII}^{\text {th }}$ as compared to group I on these days respectively. Similar results were obtained from studies of Verma and Srivastava [5]; Patra and Swarup [8] in rats using chlorpyriphos and lead respectively.

Blood glutathione (GSH) is an important naturally occurring antioxidant, which prevents free radical damage and helps in detoxification by conjugating with chemicals. In addition, GSH is pivotal to the cellular antioxidant defenses by acting as an essential co-factor for antioxidant enzymes including glutathione peroxidase (GPx) and glutathione-s-transferase (GST) $[9,10]$. Under oxidative stress, GSH is depleted by GSH related enzymes to detoxify the peroxides produced due to increased lipid peroxidation [11]. Decrease in glutathione results in the impairment of mechanism of metabolic detoxification [12]. A significant decrease in blood glutathione level (Table-2) was observed in groups II, IV ${ }^{\text {th }}$ and VIII ${ }^{\text {th }}$ on $60^{\text {th }}$ day of study. Further a significant decrease in blood glutathione level was observed on $98^{\text {th }}$ day in groups II, III, IV ${ }^{\text {th }}$, VII $^{\text {th }}$ and VIII $^{\text {th }}$ as compared to control group. Similar results were observed by Verma et al. [13] and Tandon et al. [14] in chlorpyriphos and lead treated rats respectively. Vitamin C treatment was found to increase the blood glutathione levels towards normal both in lead acetate and chlorpyriphos treated animals, which is in agreement with interactive studies of Verma et al. [13] [chlorpyriphos and vitamin C] and Bashandy [15] [lead and vitamin $\mathrm{C}$ ]. The primary role of vitamin $\mathrm{C}$ is to neutralize free radicals, both inside and outside the cells. A free radical will seek out an electron to regain their stability. Vitamin $\mathrm{C}$ being an excellent source of electrons can donate electrons to free radicals such as hydroxyl and superoxide radicals and quench their reactivity [16]. 
Table-3. Effect of oral administration of chlorpyriphos, lead acetate, vitamin C alone, and in combinations on blood superoxide dismutase activity (U/mg protein) in rats.

\begin{tabular}{|c|c|c|c|c|}
\hline Treatment group & Zero day & 30th day & 60th day & 98th day \\
\hline Group I & $60.43 \pm 2.58$ & $60.61 \pm 0.69^{c d}$ & $61.55 \pm 2.51^{c}$ & $61.59 \pm 2.47^{\mathrm{e}}$ \\
\hline Group II & $50.29 \pm 2.03$ & $46.09 \pm 2.51^{\mathrm{a}}$ & $48.00 \pm 1.09^{a}$ & $35.38 \pm 1.20^{a}$ \\
\hline Group III & $56.22 \pm 2.15$ & $57.72 \pm 1.32^{\mathrm{abc}}$ & $51.77 \pm 1.92^{\mathrm{ab}}$ & $41.20 \pm 1.60^{b}$ \\
\hline Group IV & $57.53 \pm 1.49$ & $51.65 \pm 0.88^{\mathrm{abc}}$ & $48.41 \pm 1.12^{a}$ & $38.63 \pm 1.76^{b}$ \\
\hline Group V & $56.21 \pm 2.14$ & $56.56 \pm 2.05^{\mathrm{bcd}}$ & $58.57 \pm 2.59^{c}$ & $55.92 \pm 1.72 d^{e}$ \\
\hline Group VI & $57.17 \pm 1.76$ & $58.00 \pm 2.3^{\mathrm{bcd}}$ & $56.32 \pm 2.33^{b}$ & $45.04 \pm 2.00^{\mathrm{bc}}$ \\
\hline Group VII & $52.36 \pm 0.92$ & $50.37 \pm 2.12^{\mathrm{ab}}$ & $59.61 \pm 0.88^{c}$ & $50.32 \pm 1.32^{\mathrm{cd}}$ \\
\hline Group VIII & $49.43 \pm 2.08$ & $65.71 \pm 0.89^{d}$ & $58.01 \pm 1.13^{c}$ & $52.01 \pm 1.52^{d}$ \\
\hline
\end{tabular}

Values given are mean \pm SE of the results obtained from 6 animals.

Means with at least one common superscript do not differ significantly at $5 \%(P<0.05)$

Table-4. Effect of oral administration of chlorpyriphos, lead acetate, vitamin $\mathrm{C}$ alone, and in combinations on blood catalase activity ( $\mu$ mole $\mathrm{H}_{2} \mathrm{O}_{2}$ decomposed/min/mg protein) in rats.

\begin{tabular}{|c|c|c|c|c|}
\hline Treatment group & Zero day & 30th day & 60th day & 98th day \\
\hline Group I & $60.83 \pm 1.96$ & $49.64 \pm 1.40^{b}$ & $65.21 \pm 1.27^{\mathrm{b}}$ & $54.26 \pm 2.17^{b}$ \\
\hline Group II & $60.00 \pm 2.00$ & $52.65 \pm 1.16^{\mathrm{b}}$ & $44.67 \pm 0.75^{a}$ & $38.00 \pm 1.73^{\mathrm{a}}$ \\
\hline Group III & $58.33 \pm 0.66$ & $49.76 \pm 0.88^{b}$ & $51.59 \pm 3.74^{a}$ & $42.10 \pm 1.62^{a}$ \\
\hline Group IV & $58.66 \pm 1.92$ & $42.31 \pm 1.32^{a}$ & $48.00 \pm 1.05^{\mathrm{a}}$ & $38.34 \pm 1.08^{a}$ \\
\hline Group V & $53.00 \pm 1.52$ & $53.0 \pm 2.45^{\mathrm{ab}}$ & $67.00 \pm 1.15^{\mathrm{b}}$ & $66.00 \pm 1.52^{b c}$ \\
\hline Group VI & $53.71 \pm 2.02$ & $48.30 \pm 2.10^{b}$ & $55.80 \pm 0.64^{\mathrm{ab}}$ & $61.32 \pm 2.61^{\mathrm{bc}}$ \\
\hline Group VII & $59.71 \pm 1.21$ & $59.61 \pm 2.70^{c}$ & $67.00 \pm 2.51^{\mathrm{ab}}$ & $55.50 \pm 1.30^{\mathrm{b}}$ \\
\hline Group VIII & $54.61 \pm 1.20$ & $57.00 \pm 2.60^{\circ}$ & $64.98 \pm 1.27^{b}$ & $61.32 \pm 2.32^{\mathrm{bc}}$ \\
\hline
\end{tabular}

Values given are mean \pm SE of the results obtained from 6 animals.

Means with at least one common superscript do not differ significantly at $5 \%(P<0.05)$

Superoxide radicals are produced in mitochondria and endoplasmic reticulum as a consequence of autooxidation of electron transport chain components. The major enzyme that protects against superoxide production in the body is superoxide dismutase which disproportionates the superoxide to hydrogen peroxide and oxygen [17]. Decrease in SOD activity is suggestive of excess free radical generation which impairs natural defense mechanism of the body. On $30^{\text {th }}$ day of experimentation there was a significant decrease in SOD level in groups II and VII ${ }^{\text {th }}$ as compared to group I. A significant decrease was observed in SOD level (Table-3) of groups II, III, IV ${ }^{\text {th }}$ and VI ${ }^{\text {th }}$ on $60^{\text {th }}$ and $98^{\text {th }}$ day of study. These findings are in consonance with the studies of Verma and Srivastava [5] in chlorpyriphos treated rats and El-Nekeety et al. [18] in lead treated rats. The results of ameliorative effect of vitamin $\mathrm{C}$ in the present study are in accordance with studies of Verma et al. [13] and El-Tohamy and El-Nattat [19] using chlorpyriphos and lead acetate respectively in rats. Vitamin C ameliorates the inhibitory action of lead acetate by removing ROS once formed, thus preventing free radical chain reactions.

Catalase is a haeme-containing enzyme that catalyzes the dismutation of hydrogen peroxide into water and oxygen. The enzyme is found in all aerobic eukaryotic cells and is important for the removal of hydrogen peroxide generated in peroxisomes (microbodies) by action of oxidases which are involved in $\beta$-oxidation of fatty acids and purine catabolism. Stress conditions in which there is a large free radical generation also result in the depletion in catalase activity [20]. A significant decrease in catalase activity (Table-4) was observed on $30^{\text {th }}$ day in group $\mathrm{IV}^{\text {th }}$ and in groups II, III and $\mathrm{IV}^{\text {th }}$ on $98^{\text {th }}$ and $60^{\text {th }}$ day post exposure. These findings are in agreement with previous study of and Verma et al. [13] using chlorpyriphos in rats. Ameliorative effect of vitamin $\mathrm{C}$ in the current study against decreased catalase activity is in agreement with studies of ElTohamy and El-Nattat [19] in male rabbits and Verma et al. [21] in rats using lead and chlorpyriphos respectively.

Glutathione peroxidase (GPx) is a selenium containing enzyme which reduces hydrogen peroxide forming GSH and thereby serves as an alternative means of detoxifying activated oxygen. The activity of GPx is dependent upon glutathione level. A significant decrease in GPx level (Table-5) was observed on $30^{\text {th }}$ day in group III, on $60^{\text {th }}$ day in groups II, III and IV th $^{\text {th }}$ and on $98^{\text {th }}$ day of experimentation in group $\mathrm{VI}^{\text {th }}$ on as compared to control group. Present findings of decreased GPx and GST levels are in agreement with studies of Verma and Srivastava [5] and Jackie et al. [22] in chlorpyriphos and lead treated rats, respectively. The ameliorative effects of vitamin $\mathrm{C}$ observed in the present study are in agreement with studies of Nagat et al. [23] on chlorpyriphos in rats and El-Tohamy and El-Nattat [19] on lead acetate in rabbits.

GSTs are a major group of enzymes that constitute about 10 per cent cytosolic protein in some mammalian organs. GST catalyze the conjugation of reduced glutathione via the sulfhydryl group to electrophilic centers on a wide variety of substances. This catalytic activity of combined glutathione with electrophiles helps in excretion of toxicant from the cells and protects the tissues from oxidative stress [10]. In the current study a significant decrease in GST level (Table-6) was observed on $98^{\text {th }}$ day in groups II, III and $\mathrm{IV}^{\text {th }}$ as compared to control group. 
Table-5. Effect of oral administration of chlorpyriphos, lead acetate, vitamin $\mathrm{C}$ alone, and in combinations on blood glutglutathione peroxidase activity (U/mg protein) in rats.

\begin{tabular}{lllc}
\hline Treatment group & Zero day & 30th day & 60th day \\
\hline Group II & $14.78 \pm 0.23$ & $14.71 \pm 1.15^{\mathrm{b}}$ & $14.86 \pm 0.63^{\mathrm{bc}}$ \\
Group II & $14.01 \pm 0.35$ & $14.36 \pm 0.16^{\mathrm{ab}}$ & $12.96 \pm 0.18^{\mathrm{a}}$ \\
Group III & $15.34 \pm 0.30$ & $12.46 \pm 0.19^{\mathrm{a}}$ & $13.00 \pm 0.07^{\mathrm{ab}}$ \\
Group IV & $15.59 \pm 0.50$ & $12.63 \pm 0.31^{\mathrm{ab}}$ & $11.96 \pm 0.27^{\mathrm{a}}$ \\
Group V & $14.90 \pm 0.58$ & $14.65 \pm 0.18^{\mathrm{ab}}$ & $15.42 \pm 0.21^{\mathrm{bc}}$ \\
Group VI & $14.89 \pm 0.58$ & $14.39 \pm 0.63^{\mathrm{ab}}$ & $14.60 \pm 0.30^{\mathrm{bc}}$ \\
Group VII & $14.39 \pm 0.30$ & $13.97 \pm 0.26^{\mathrm{ab}}$ & $11.32 \pm 0.19^{\mathrm{abc}}$ \\
Group VIII & $14.61 \pm 0.30$ & $18.33 \pm 0.60^{\mathrm{ab}}$ & $13.94 \pm 0.23^{\mathrm{cde}}$ \\
\hline
\end{tabular}

Values given are mean \pm SE of the results obtained from 6 animals.

Means with at least one common superscript do not differ significantly at $5 \%(P<0.05)$

Table-6. Effect of oral administration of chlorpyriphos, lead acetate, vitamin $\mathrm{C}$ alone, and in combinations on blood glutathione-S-transferase activity ( $\mu$ mole of conjugate of GSH-CDNB / $\mathrm{min} / \mathrm{mg}$ plasma protein) in rats.

\begin{tabular}{llll}
\hline Treatment group & Zero day & 30th day & 60th day \\
\hline Group I & $0.015 \pm 0.001$ & $0.017 \pm 0.0045$ & $0.014 \pm 0.0027^{\mathrm{a}}$ \\
Group II & $0.017 \pm 0.0015$ & $0.015 \pm 0.003$ & $0.0083 \pm 0.00041^{\mathrm{ab}}$ \\
Group III & $0.019 \pm 0.0017$ & $0.016 \pm 0.0014$ & $0.018 \pm 0.0006^{\mathrm{a}}$ \\
Group IV & $0.018 \pm 0.007$ & $0.017 \pm 0.003$ & $0.0079 \pm 0.0002^{\mathrm{ab}}$ \\
Group V & $0.17 \pm 0.0028$ & $0.016 \pm 0.0031$ & $0.0089 \pm 0.00064^{\mathrm{b}}$ \\
Group VI & $0.016 \pm 0.00153$ & $0.018 \pm 0.0008$ & $0.0061 \pm 0.00018^{\mathrm{b}}$ \\
Group VII & $0.018 \pm 0.0017$ & $0.02 \pm 0.0013$ & $0.0095 \pm 0.0001^{\mathrm{a}}$ \\
Group VIII & $0.017 \pm 0.0023$ & $0.0165 \pm 0.00058$ & $0.01 \pm 0.004^{\mathrm{a}}$ \\
\hline
\end{tabular}

Values given are mean \pm SE of the results obtained from 6 animals.

Means with at least one common superscript do not differ significantly at $5 \%(P<0.05)$

\section{Conclusions}

Oxidative stress parameters, like lipid peroxidation, CAT, SOD, GPx, GSH, GST were more significantly altered with co-administration of chlorpyriphos and lead acetate as compared to their individual administration. Studies revealed that lead acetate has the potentiating effect on the capability of chlorpyriphos to induce alterations in antioxidant indices in rats. Ameliorative effect of vitamin $\mathrm{C}$ on oxidative stress induced by chlorpyriphos or lead acetate was more prominent when given alone as compared to that when given in combination with chlorpyriphos and lead acetate.

\section{Authors' contribution}

NAN: Overall monitoring and implementation of study, data collection, tabulation, drafted and revised the manuscript. MS: Provided necessary permission and technical guidance. HAW, PAP and NAB: Provided necessary help for data collection during the study. FAZ and WHR: Carried out the statistical analysis. All authors read and approved the final manuscript.

\section{Acknowledgements}

The authors are grateful to Indian Institute of Integrative Medicine, Council of scientific and industrial research Laboratory, Jammu for providing experimental animals.

\section{Competing interests}

Authors declare that they have no competing interest.

\section{References}

1. Jamshidi H. R., Ghahremani M. H., Ostad S. N., Sharifzadeh M., Dehpour A. R. and Abdollahi. M. (2009) Effects of diazinon on the activity and gene expression of mitochondrial glutamate dehydrogenase from rat pancreatic Langerhans islets. Pest. Biochem. and Physiol. 93:23-27.

2. Soltatinejad K. and Abdollahi M. (2009) Current opinion on the science of organophosphate pesticides and toxic stress: a systematic review, Med. Sci. Monit. 15:75-90.

3. Afaf, A. El-Kashoury and Hanan, A. Tag El-Din. (2010) Effect on Testicular Biochemistry of Male Albino Rats. Journal of American Science; 6(7): 252-261.

4. Kelly S. A., Havrilla C. M., Brandy T. C., Abramo K. H and Lewin E. D. (1998) Oxidative stress in toxicology: Established mammalian and piscine model systems. Environment and Health Perspective, 106(7): 375-384.

5. Verma R. S and Srivastava N.(2003) Effects of chlorpyriphos on thiobarbituric acid reactive substances, scavenging enzymes and glutathione in rats tissues. Indian Journal Biochemistry and Biophysics, 40: 423-428.

6. Mustafa C., Mehmet E., Buyukokurog, Ahmet B., Fatih A. and Levent O. (2010) Effects of vitamin $E$ and selenium on tissue bio-element status in organophosphate toxicity of rats. Pesticide Biochemistry and Physiology, 98:9-18.

7. Flora S. J. and Tandon S. K (1986) Preventive and therapeutic effects of thiamine, vitamin and their combination in lead intoxication. Acta Pharmacology Toxicology, 58:374-378.

8. Patra R. C. and Swarup D. (2001) Effect of lead on erythrocyte antioxidant defense, lipid peroxide level and $\mathrm{L}$ -methionine on lead induced oxidative stress to the liver, kidney and brain rats. Toxicology 162:81-88.

9. Mascio P., Murphy M. E. and Sies H. (1991) Antioxidant defense systems: the role of carotinoids, tocopherols, and thiols. American Journal of Clinical Nutrition 53:194-200.

10. Hayes J. D. and Paiford D. J. (1995) The glutathione-Stransferase supergene family. Regulation of GST and the contribution of the isoenzymes to cancer chemoprotection and drug resistance. Critical Reviews in Biochemistry and Molecular Biology, 30: 445-600.

11. Cathcart R. F. (1985) Vitamin C: the nontoxic, non ratelimited, antioxidant free radical scavenger, Medical Hypothesis, $18: 61-77$.

12. Verma R. S and Srivastava N. (2001) Chlorpyriphos induced alterations in levels of thiobarbituric acid reactive substances 
and glutathione in rat brain. Indian Journal of Experimental Biology 39: 174 - 178.

13. Verma, R. S., Mehta, A. and Srivastava, N. (2007) In-vivo Chlorpyriphos induced oxidative stress: Attenuation by antioxidant vitamins. Pesticide Biochemistry and Physiology, 88: 191-196.

14. Tandon, S. K, Singh, S., Prasad S., Srivastava, S. and Siddiqui, M. J. K. (2002) Reversal of lead induced oxidative stress by chelating agent, Autoxidation or their combination in rats. Environment Research 90:61-66.

15. Bashandy, S. A. E (2006) Beneficial Effect of Combined Administration of Vitamin C and Vitamin E in Amelioration of Chronic Lead Hepatotoxicity. The Egyptian Journal of Hospital Medicine, 23:371 -384.

16. Bendich, A. (1990) Antioxidant micronutrients and immune responses, New York Academy of Sciences, New York, p. 175, Retrieved on 9 August 2008.

17. McCord, J. M. and Fridovich. (1969) Superoxide dismutase: an enzymic function for erythrocuprein (hemocuprien). Journal of Biological Chemistry, 244: 6049-6055.

18. El-Nekeety, A. A., El-Kady, A. A., Soliman, M. S., Hassan, N. S. and Abdel-Wahhab, M. A (2009) Protective effect of Aquilegia vulgaris (L.) against lead acetate-induced oxidative stress in rats. Food Chemical Toxicology, 47: 2209-15.

19. El-Tohamy, M. M. and El-Nattat, W. S. (2010) Effect of antioxidant on lead-induced oxidative damage and reproductive dysfunction in male rabbits. Journal of American Science, 6(11):123-127.

20. Hertwig and Feierabend, J.(1992) Light dependence of catalase synthesis and degradation in leaves and the influence of interfering stress conditions. Plant Physiology, 100: $1547-1553$.

21. Verma, R. S., Mehta, A. and Srivastava, N. (2009) Comparative studies on chlorpyriphos and methyl parathion induced oxidative stress in different parts of rat brain: Attenuation by antioxidant vitamins. Pesticide Biochemistry and Physiology, 95 152-158.

22. Jackie, T., Nagaraja, H. and Srikumar, C. (2011) Antioxidant effects of Etlingera elatior flower extract against lead acetate induced perturbations in free radical scavenging enzymes and lipid peroxidation in rats. BMC Research Notes, 4:67.

23. Nagat, A., Kawther, E. L., Fatma, M., Abdel Khalek. and ElSebae. (2011) Protective effect of vitamin C against chlorpyriphos oxidative stress in male mice. Pesticide Biochemistry and Physiology 97: 7-12. 